\title{
Climate Justice Planning in Global South: Applying a Coupled Nature-Human Flood Risk Assessment Framework in a Case for Ho Chi Minh City, Vietnam
}

\author{
Chen-Fa Wu ${ }^{1}\left(\mathbb{D}\right.$, Szu-Hung Chen ${ }^{2}$, Ching-Wen Cheng ${ }^{3}$ and Luu Van Thong Trac $1, *(\mathbb{C}$ \\ 1 Department of Horticulture, National Chung Hsing University, Taichung City 402, Taiwan; \\ cfwu@dragon.nchu.edu.tw \\ 2 International Master Program of Agriculture, National Chung Hsing University, Taichung City 402, Taiwan; \\ vickey@dragon.nchu.edu.tw \\ 3 The Design School, Arizona State University, Tempe, AZ 85287, USA; Chingwen.Cheng@asu.edu \\ * Correspondence: tracluuvanthong@gmail.com; Tel.: +886-4-2285-9125
}

Citation: Wu, C.-F.; Chen, S.-H.; Cheng, C.-W.; Trac, L.V.T. Climate Justice Planning in Global South: Applying a Coupled Nature-Human Flood Risk Assessment Framework in a Case for Ho Chi Minh City, Vietnam. Water 2021, 13, 2021. https:// doi.org/10.3390/w13152021

Academic Editor: Roger Falconer

Received: 19 June 2021

Accepted: 22 July 2021

Published: 23 July 2021

Publisher's Note: MDPI stays neutral with regard to jurisdictional claims in published maps and institutional affiliations.

Copyright: () 2021 by the authors. Licensee MDPI, Basel, Switzerland. This article is an open access article distributed under the terms and conditions of the Creative Commons Attribution (CC BY) license (https:// creativecommons.org/licenses/by/ $4.0 /)$.

\begin{abstract}
Developing countries in the global south that contribute less to climate change have suffered greater from its impacts, such as extreme climatic events and disasters compared to developed countries, causing climate justice concerns globally. Ho Chi Minh City has experienced increased intensity and frequency of climate change-induced urban floods, causing socio-economic damage that disturbs their livelihoods while urban populations continue to grow. This study aims to establish a citywide flood risk map to inform risk management in the city and address climate justice locally. This study applied a flood risk assessment framework integrating a coupled nature-human approach and examined the spatial distribution of urban flood hazard and urban flood vulnerability. A flood hazard map was generated using selected morphological and hydro-meteorological indicators. A flood vulnerability map was generated based on a literature review and a social survey weighed by experts' priorities using the Fuzzy Delphi Method and Analytic Network Process. Vulnerability indicators including demographic characteristics, infrastructure, and land use patterns were used to generate a flood vulnerability map. The results illustrate that almost the entire central and northeastern parts of the city are at high flood risk, whereas the western part is at low flood risk. The findings have implications in urban planning via identifying risk hot spots in order to prioritize resources for mitigating hazards and enhancing community resilience to urban floods.
\end{abstract}

Keywords: Fuzzy Delphi Method; analytical network process; flood hazard; vulnerability; flood risk; Ho Chi Minh City

\section{Introduction}

In the global climate change forum, climate justice is a great concern for countries that contribute less to greenhouse gas emissions yet suffer more from climate change impacts. Developing countries in the global south, such as Vietnam, are facing climate justice on top of urbanization challenges. Ho Chi Minh City (HCMC, formerly known as Saigon before 1975), the largest city in Vietnam with a population of over eight million, is the economic engine of the country. The city has contributed tremendously to the economic development and process of industrialization in southern Vietnam and north to the Mekong Delta since the late 1980s in a liberalization process known as "Đổi mới" in Vietnamese [1,2]. In the meantime, the increased disparity of economic opportunities between rural and urban areas compounded with a lack of comprehensive growth management and land use policies across the country [3] have resulted in fluxes of migrants from the countryside to cities over time and accelerated the urbanization process in the HCMC metropolitan area [2]. Anthropogenic activities in the urbanization process have made significant impacts on the degradation of ecosystem structures and functions. The increased urban development has 
led to a notable amount of land cover change from vegetation to compacted impervious surfaces (i.e., asphalt, concrete, pavers, building footprints) [2,4,5], resulting in the loss of regulatory ecosystem services for flood mitigation [6]. Unsustainable and imbalanced development continue to aggravate risks and make the city more vulnerable to disasters [7]. Climate change presents a particular challenge to urban areas and their expanding populations [8]. Combined with uncertainty in the increased probability of extreme storm events, typhoons, and climate change-induced flooding [9-17], more communities are likely to be exposed to flooding hazards and suffer from losses and disruptions from disasters. The greatest hits are in vulnerable communities and developing cities, where government investment for public stormwater infrastructure, flood-proof buildings, and risk management services have not met the needs in local communities and population growth [18], posing climate justice and urban resilience concerns in cities [19,20]. In addition, coastal areas and deltas are exposed to sea-level rises and greater water level changes due to climate change, resulting in a higher probability of floods occurring in these flood-prone regions [21]. Consequently, combined factors of high population concentration and low investment in infrastructure upgrades have increased flood risks in urbanized areas in Vietnam [22].

HCMC reflects a climate justice city for studying vulnerability to urban floods under climate change impacts [23]. The extent of flooding in HCMC has increased in recent years. In 2008, a total number of citywide submerged locations reached 126 points [24], where urban development construction projects have increased 8-fold, and the population has doubled since the 1990s [25]. In 2009, 235 of the total 322 communes and wards were flooded, regularly affecting about 971,000 inhabitants ( $12 \%$ of the city's population) and covering nearly 140,000 ha (68\% of the city area) [26]. Due to the constantly extending impervious surface, the city added 23 more new flooded sites in 2014 [24]. Under climate change scenarios, urban floods are projected to affect 30 more communities, adding to total flood-prone areas to be $71 \%$ of the city's residential areas and affecting $48 \%$ of the city population by 2050 [26]. Each year, it is estimated that the damage caused by inundation in the city is more than 1500 billion VND (65 million USD) [27]. The city's transportation network is predicted to be exposed to damage or disruption due to extreme and frequent floods. Economic disruption could be devastating by preventing workers from reaching the workplace, and goods cannot be supplied. In case of sewage system overflows in flood events, the spread of pathogens such as cholera and diarrhea would exist, which endangers public health when people contact contaminated water sources [26].

Currently, there is a lack of comprehensive study on future urban flooding and its socio-economic impacts in HCMC's official reports. Understanding of urban flooding vulnerability and spatial relationship is crucial to facilitate better mitigation and preparedness policies in urban planning and design and to address climate justice in cities $[19,20,28]$. This project aims to provide an urban flooding vulnerability assessment framework and create an urban flood risk map for HCMC in order to inform urban planners for policy making to build urban resilience and address climate justice in communities.

\section{Study Area}

HCMC is a low-lying coastal metropolis situated in the southern region of Vietnam [23] within the northern boundary of the Mekong Delta [25] in the Saigon River Basin [29] (Figure 1), with an urban area of $494.01 \mathrm{~km}^{2}$. However, $65 \%$ of the city's territory is located between 0 and $1.5 \mathrm{~m}$ [25], exposing to high tidal events [23]. In addition, HCMC is in a tropical monsoon climate characterized by two distinct wet (May to November) and dry seasons [23,30], with a period of heavy precipitation between September and October [23]. According to the city's 11 meteorological measuring stations collecting data for the Center for Hydro-Meteorological Data of Vietnam, the annual average precipitation in HCMC is about $1900 \mathrm{~mm}$. Heavy rains exceeding $100 \mathrm{~mm}$ has become more frequent in the recent decade, which remarkably increased from five to 20 events per year between 2009 and 2018. Associated with poor sewage infrastructure, the intensity of heavy precipitation 
intensity makes this megacity vulnerable to urban flash and pluvial floods [31] in addition to seasonal riparian and coastal tidal floods [24]. A total of 66 tidal events that exceeded alert level III (level of river water rises over $1.6 \mathrm{~m}$ ) has continuously occurred over three years 2017-2019, including record-high peak events at Saigon and Dong Nai Rivers. The combined tidal, riparian, and pluvial floods have caused severe inundation and threatened the livelihood of the communities [32].

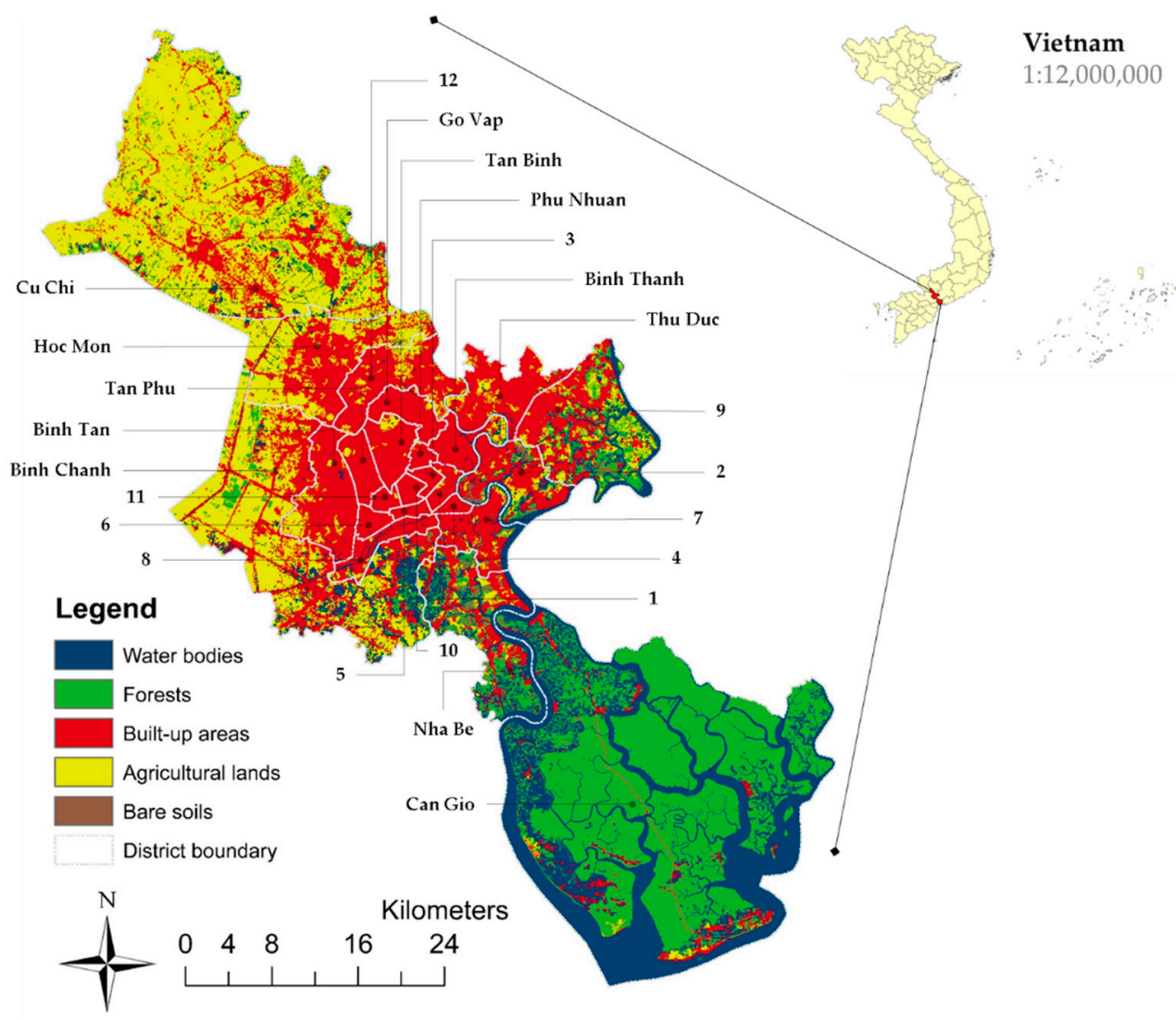

Figure 1. The land use map of Ho Chi Minh City, Vietnam, in 2018.

\section{Methods}

\subsection{Coupled Nature-Human Flood Risk Assessment Framework}

The coupled nature-human flood risk assessment framework aims to integrate social and ecological factors that are critical in identifying place-based flood hazard exposures and vulnerability [33,34] (Figure 2). Flood hazards are defined by a high probability of being inundated with floodwater over a specified duration [35-39]. Flood hazard assessment comprises selective geomorphological and hydro-meteorological variables [40-43]. Vulnerability refers to the intrinsic sensitivity of a component at risk exposed to hazards plus the adaptive capacity to cope with impacts from disasters [44]. Flood vulnerability encompasses human development, infrastructural susceptibility, and resilience capacity $[41,45]$ (Table 1). 


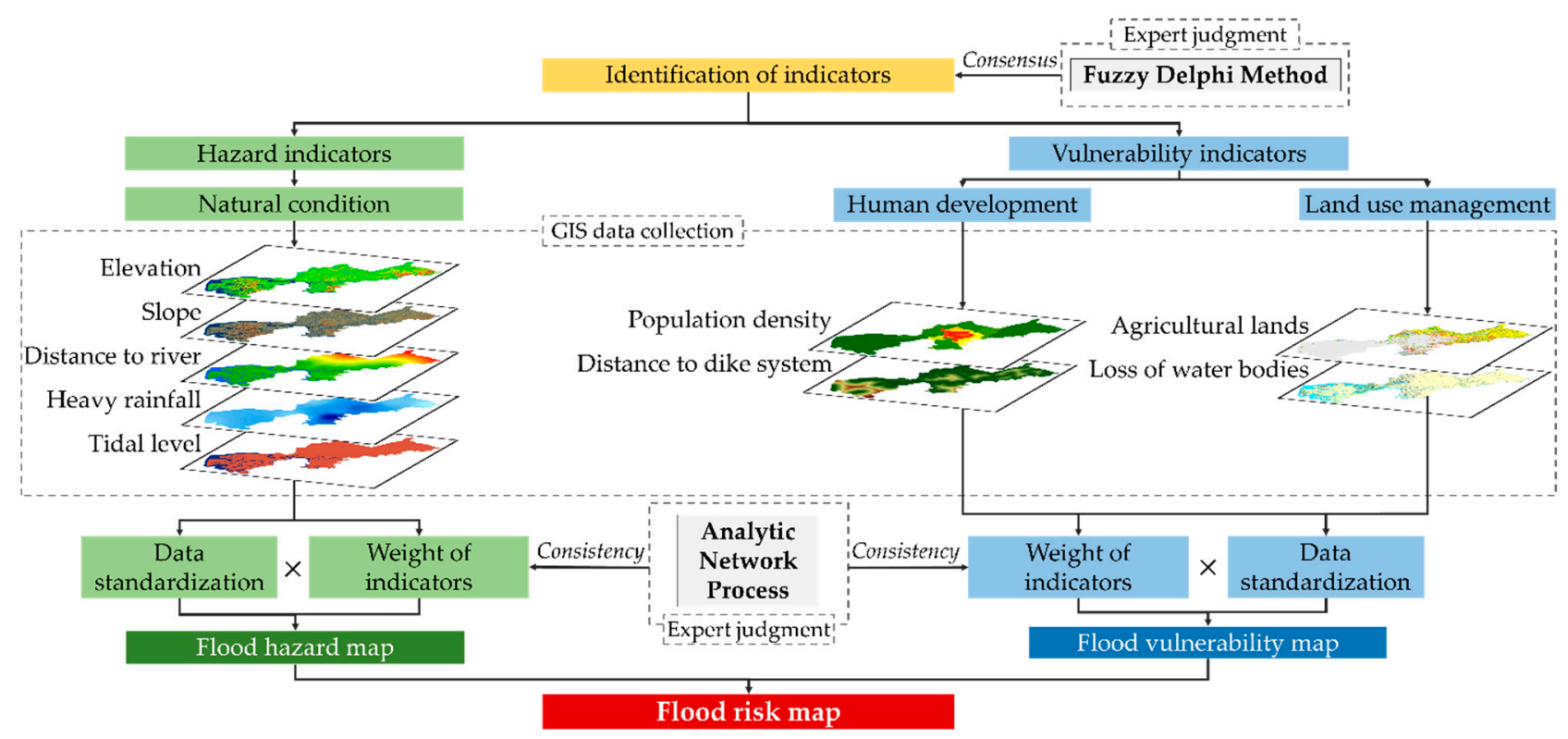

Figure 2. The coupled nature-human flood risk assessment framework.

In order to understand the flood risk at a local level, we engaged stakeholders to reflect on the geographical and climatic characteristics of the place, extreme weather and associated environmental degradation patterns, impacts from rapid population growth, and unplanned urbanization combined with socio-economic conditions in the development history and aspirations of HCMC, providing fundamental information to urban planners to prioritize potential resources for reducing urban flood. A social survey was conducted from 1 January to 15 February 2020 in HCMC. Six stakeholders who participated in this study include university researchers who often provide scientific data and policy recommendations to the city in the fields of agriculture, water resources management, land management, GIS and remote sensing, water resources, and environment in state research institutes. According to the interviews, three dimensions related to the urban flood in HCMC - natural condition, human development, and land use managementrelated to flooding in HCMC. The natural condition includes topography and extreme weather events associated with flooding conditions $[23,24]$. Human development refers to increased population density and the needs for infrastructure construction and updates for enhancing coping capacity with floods [24]. Governmental weakness demonstrates the unsustainability in land use management, which can be observed by the misuse of urban planning [3].

There are three government projects $(S)$ that represent current flood management strategies: $\left(\mathrm{S}_{1}\right)$ Drainage system improvement in Ho Chi Minh City drainage system master plan up to 2020 [46]; $\left(\mathrm{S}_{2}\right)$ Water retention pool in Ho Chi Minh City drainage system master plan up to 2020 [46]; $\left(\mathrm{S}_{3}\right)$ Tidal control gate to mitigate tidal flooding in Ho Chi Minh City considering climate change factors (phase 1) [47]. These projects are in the pipeline and are expected to be effective flood mitigation and adaptation strategies in terms of reducing the frequency of flood disasters and adverse effects of flooding impacts.

The Fuzzy Delphi Method (FDM) was used to select critical indicators based on stakeholders' judgments. Furthermore, Analytic Network Process (ANP) using the weightbased evaluation was used to establish a ranking for indicators and adaptation strategies. Moreover, geographic information systems (GIS) and remote sensing data were used to process and standardize each indicator and produce spatial layers. The results were combined with the weighted indicators to create flood hazard and flood vulnerability maps, respectively, and a composite map for assessing flood risk. 
Table 1. The list of flood hazard and vulnerability indicators identified for HCMC.

\begin{tabular}{|c|c|c|c|c|}
\hline Dimension & Indicator & Source & Justification (Flood-Related Relationship) & References \\
\hline \multirow[t]{5}{*}{ Natural condition } & Elevation & NASA & $\begin{array}{l}(-) \text { Low-lying terrain is more likely to be } \\
\text { flooded by water flowing from higher into } \\
\text { lower altitude areas. }\end{array}$ & {$[4,48-50]$} \\
\hline & Slope & NASA & $\begin{array}{l}(-) \text { The slope affects the flow rate of the water. } \\
\text { An area with a more rough slope causes the } \\
\text { water to flow speedily where the slope is more } \\
\text { gentle. }\end{array}$ & {$[18,51]$} \\
\hline & Distance to river * & NASA & $\begin{array}{l}(-) \text { Areas further from the river basins have } \\
\text { less possibility of floods, while overflowing } \\
\text { water from major rivers often causes flooding } \\
\text { in neighboring areas. }\end{array}$ & {$[49,51,52]$} \\
\hline & Heavy rainfall * & CHMD & $\begin{array}{l}\text { (+) If natural watercourses beyond the coping } \\
\text { capacity to convey the excess precipitation } \\
\text { during heavy rains, flooding will occur and } \\
\text { devastate the areas it sweeps through. }\end{array}$ & {$[42,53]$} \\
\hline & Tidal level * & ICOE & $\begin{array}{l}(+) \text { Influenced by the semi-diurnal tidal waves } \\
\text { and high flows from upstream rivers, the river } \\
\text { basins are prone to inundation due to the } \\
\text { overflow of high tide. }\end{array}$ & {$[24,54,55]$} \\
\hline \multirow[t]{3}{*}{ Human development } & Population growth rate & $\mathrm{HCSO}$ & $\begin{array}{l}(+) \text { In areas where the urbanization process is } \\
\text { strongly perusing, the rapid population growth } \\
\text { has both an effect on soil structure and } \\
\text { vegetation and overloading the drainage } \\
\text { system. }\end{array}$ & [56] \\
\hline & Population density * & $\mathrm{HCSO}$ & $\begin{array}{l}(+) \text { The increasing rate of population density } \\
\text { along the riverine floodplain is observed } \\
\text { positively related to the likelihood of flood } \\
\text { vulnerability, leading to the expansion of the } \\
\text { impervious area. }\end{array}$ & {$[2,41]$} \\
\hline & Distance to dike system * & ICOE & $\begin{array}{l}(-) \text { Areas sheltered by dikes receive effectively } \\
\text { physical and human protection from a } \\
\text { hydraulic infrastructure in recurrent riverine } \\
\text { flooding. }\end{array}$ & {$[57,58]$} \\
\hline \multirow[t]{5}{*}{ Land use management } & Forests & USGS & $\begin{array}{l}(-) \text { Forests function to prevent flooding from } \\
\text { upstream rivers and mangroves to reduce the } \\
\text { influence of tides from the sea, which pushes } \\
\text { the rise of river water. }\end{array}$ & [59-61] \\
\hline & Loss of forest areas & USGS & $\begin{array}{l}(+) \text { Deforestation loses natural shields from the } \\
\text { influence of floods. The intensity of floods } \\
\text { occurs stronger in areas with deforestation. }\end{array}$ & [59] \\
\hline & Agricultural lands & USGS & $\begin{array}{l}(-) \text { The temporary absorption of runoff on the } \\
\text { surface of agricultural land through the } \\
\text { permeability of the soil structure increases the } \\
\text { likelihood of flood reduction. }\end{array}$ & [62] \\
\hline & Loss of agricultural lands & USGS & $\begin{array}{l}\text { (+) The agricultural land of HCMC noticeably } \\
\text { decreased between } 2010 \text { and } 2017 \text {. The } \\
\text { encroachment reduces the agricultural land and } \\
\text { increases problems overwhelming urban floods. }\end{array}$ & [63] \\
\hline & Loss of water bodies * & USGS & $\begin{array}{l}(+) \text { The encroachment of construction schemes } \\
\text { along water bodies on natural water bodies is } \\
\text { directly proportional to the occurrence of floods. } \\
\text { This could be due to the loss of natural flooding } \\
\text { protection systems. }\end{array}$ & {$[64]$} \\
\hline
\end{tabular}

CHMD = Center for Hydro-Meteorological Data; ICOE = Institute of Coastal and Offshore Engineering; HCSO = Ho Chi Minh City Statistical Office; NASA = United States National Aeronautics and Space Administration; USGS = United States Geological Survey. * means criteria mentioned by more than $80 \%$ of stakeholders. 


\subsection{Establish Stakeholder-Driven Ranked Indicators}

In order to rank and prioritize indicators, several methodologies have been implemented in disaster adaption, particularly flood management, including the Fuzzy Delphi Method (FDM) [65], which is an Analytic Network Process (ANP) approach [66]. The ANP is a theory for measuring intangible parameters relative to one another. The process should be used to make multicriteria assessments that include incentives, opportunities, expenses, and hazards. The principles are built in stages and contrasted with real-life judgment examples [67]. Based on interdependent relationships between indicators, the model of ANP is prospective in ranking indicators of community and creating weight-based indicators more accurately through a network process. The fuzzy Delphi with set theory approach is an improved Delphi variant using triangulation statistics to distinguish consensus among stakeholders [68]. The effectiveness of the standard Delphi approach could be significantly upgraded by applying the algorithms and adding the dual triangular fuzzy number [69]. This enables the amended algorithm to incorporate stakeholders' opinions more accurately and shape a consensus, eliminating asking stakeholders repeatedly. Since missing or unreliable data create specific judgment problems, it is best to display data rather than definitive figures, and fuzzy sets are used to analyze stakeholders' opinions [70,71]. Studies combined the FDM with the ANP as an evaluation framework to provide a paradigm for assessing criteria. First, various abstruse and qualitative parameters can be simplified into basic and representative measurement criteria using the objective quantitative formula of FDM. Secondly, ANP can expose the interdependent relationships of the problem by using variables derived by FDM [72].

\subsection{Selecting Indicators Using Fuzzy Delphi Method}

We began our quest by seeking scientists acquainted with environmental science, landscaping, water resources, land management, geographic information system, remote sensing, and agriculture through the "snowball sampling" technique [73]. A group of 20 indigenous researchers with an average of 15 years of seniority in related studies or teaching experience was formed: 15 are teaching at universities, and 5 belong to governmental research institutes. We sent questionnaires on 29 April 2020 and received 17 responses until 30 June 2020. Eliminating three invalid responses, a total of 14 valid responses were used for analysis.

The social survey includes an FDM questionnaire in three sections. The first section explained the study purposes and illustrated a hierarchical structure of the proposed flood risk assessment framework, which was followed by a brief introduction to FDM, including examples of how the method is used to select indicators. The second section illustrated the importance of identifying indicators through both qualitative and quantitative evaluation. In qualitative judgment, stakeholders may choose either the "important" or "remove" option for each indicator. The quantitative judgment was based on a Likert scale between 0 and 10, whereas 0 indicates the least important and 10 indicates the most important indicator [74]. The last section was designed to collect personal information.

According to the given Likert scale, each stakeholder provided the interval values of importance based on his individual judgments for each evaluation criterion, which is denoted by $i$ in the second section. Subsequently, a minimum interval value is defined to indicate "the most conservative cognition $\left(C_{L}^{i}\right)^{\text {" }}$ of a quantified criterion. In contrast, the highest interval value specifies "the most optimistic cognition $\left(O^{i} U\right)^{\prime}$ " [75,76]. To test the consensus among stakeholders, we applied the following parameters defined by Chou et al. in 2014 [75]: minimum $C_{L}^{i}$, maximum $C^{i} u$, and geometric mean $C^{i}{ }_{M}$ of "the most conservative cognition" and the parameters of minimum $O_{L}^{i}$, maximum $O_{U}^{i}$, and geometric mean $O^{i}{ }_{M}$ of "the most optimistic cognition" [75]. The FDM survey is considered complete when the indicators achieve convergence (each verification value is greater than 0 ) because of the consistency in stakeholders' consensus. Moreover, the importance of each indicator is directly proportional to the value of $C^{i}$. The standard threshold value was determined by the proposed Likert scale and each stakeholder's point of view, affecting the number 
of important indicators that are selected from the evaluation results using the FDM. This study calculated a threshold determined by the multiplication of arithmetic mean of expert consensus $\left(G^{i}\right)$ with a constant of $90 \%$ [75]. Consequently, the value of indicators below the threshold would be removed from the results.

\subsection{Prepare Spatial Layers of Indicators}

\subsubsection{Natural Condition}

Topography is a critical geographical characteristic for defining flood hazards [77]. The high spatial resolution of remote sensing is critical to reproduce place-based flood dynamics [78,79]. Due to the flexibility in representing terrain for multiple landforms [80] and being widely used in mapping flood-prone areas [41,81-83], the Advanced Spaceborne Thermal Emission and Reflection Radiometer (ASTER) Global Digital Elevation Model Version 3 (GDEM) obtained via NASA Earthdata was employed to estimate an elevation map corresponding to the scale of 1:600,000 with moderate spatial resolutions of $30 \times 30 \mathrm{~m}$, which is a resolution used throughout this study. Then, this GDEM was used for generating a slope map with the measurement of the degree unit.

GDEM was also used to extract the area boundaries of the river system [77,84]. The grading approach used to approximate a raster map for distance to river was generated by the ArcGIS Euclidean Distance tool. For mapping heavy rainfall distribution, nine meteorological stations distributed around HCMC were selected as well as measured values of monthly precipitation in the period of 2010-2019. Considering the rainfall observations in the city, an approach of recurrence intervals of eight years (approximately 100 months) was applied to calculate based on the total monthly precipitation for each station [85] associated with the rainfall intensities up to $674.68 \mathrm{~mm}$. Identifying the probability of occurrence and recurrence intervals can represent a long-term series and statistical inferences of occurred heavy rainfall $[86,87]$. Then, the rainfall distribution across the study area was constructed through a geostatistical interpolation tool that interpolates a surface from points using an inverse distance weighted (IDW) technique [45,53].

The hydrogeomorphic models have flourished in many studies based on the increasing impetus available to the GDEM [88-91]. These models delineated the areas subjected to inundation through a direct comparison between the states of a river and the surrounding terrain elevation automatically. This study collected the measured record of daily tidal levels from 2017 to 2019 through the hydrological stations distributed across the city and calculated a maximum $(1.8 \mathrm{~m})$, a minimum $(-2.50 \mathrm{~m})$, and an average $(0.31 \mathrm{~m})$, respectively. Based on this calculation, we reclassified the GDEM into five classes using a scale from 1 to 5 associated with the extent of flood vulnerability [41]. Since the default value of GDEM is integers and other accompanying factors combining the tide level raises such as heavy rain were considered, we ranked the value of GDEM as 0: very high, 1: high, 2: moderate, 3: low, and higher than or equal to 4: very low.

\subsubsection{Human Development}

The population density (persons $/ \mathrm{km}^{2}$ ) of 24 districts in 2018 was collected from the Statistics Office of HCMC and then processed in the ArcGIS. A dike system stretching along the riverside was used as an indicator for the fighting-calamity capability of flood control projects and had the function of protecting residents and highly concentrated asset values [92,93]. A map of the dike system was provided by the Institute of Coastal and Offshore Engineering. A map of the distance to the dike system was generated using the ArcGIS Euclidean Distance tool.

\subsubsection{Land Use Management}

All satellite imageries were presented and pre-processed utilizing ENVI 5.3 imagine software for the radiometric and geometrical corrections. The geodata and the preprocessed satellite imageries were projected into the geographical coordinate system as WGS84/Universal Transverse Mercator/Zone 48 North [63]. According to an HCMC 
Statistical Office regulation, this city's urban area comprises five components: forests, water bodies, agricultural lands, built-up areas, and bare land. A pixel-based image processing was undertaken using the Maximum Likelihood algorithm through the supervised classification for land patterns classification in order to find areas with the same spectral reflection [94]. Then, we set them to intended class objects based on external knowledge of the study area, as shown in the image [95]. In classification accuracy assessment, the necessary reference data were collected, which was used to determine whether the classified Landsat images can be used for further comparative analysis of post-classification [96]. Overall accuracy $(\mathrm{OA})$ and Kappa coefficient $\left(\mathrm{K}_{\mathrm{value}}\right)$ were statistical parameters used for the assessment of classification accuracy, which were computed using randomly sampled truth points for 2010 and 2018 [63,97]. The result of the classification accuracy assessment showed the overall high proficiency of supervised classification algorithms used for producing land cover maps in 2010 and 2018, with the $\mathrm{OA}=89.60 \%$, $\mathrm{K}_{\text {value }}=0.87$, and $\mathrm{OA}=87.60 \%, \mathrm{~K}_{\text {value }}=0.84$ for classification of Landsat images in 2010 and 2018, respectively, which are over the limitation of $85 \%$. Thus, the results of the classification method and ground control points are reasonably compared and considered acceptable for the following land cover type change detection [98].

Each parameter of agricultural lands and loss of water bodies with functional relationships of very low, low, moderate, very high, and high to flood risk intensity was ranked associated with a scale from 1 to 5 : very low (1), low (2), moderate (3), high (4), and very high (5). This assessment was assigned regarding the direct or inverse flood-related justification of individual factors with flood risk intensity [41]. The detailed ranking value of transformative classes is shown as follows: unchanged $=1$, new agricultural lands or new water bodies $=2$, agricultural lands or water bodies respectively changed into water bodies or agricultural lands and forest $=3$, other transformations $=4$, and agricultural lands or water bodies respectively changed into built-up areas and bare soils $=5$.

\subsection{Computing Stakeholder-Driven Weighted Indicators}

The design of an ANP questionnaire included two sections. The first section stated our study purposes and presented a proposed framework to compute the weight of the criteria that were selected by FDM with suggested governmental projects. Then, a brief introduction of ANP, including examples, was presented to confirm the stakeholders' understanding of expressing their evaluation based on Saaty's scale [99]. The second section evaluates the weight and rank of the interdependent relation of criteria and governmental projects. We sent out 14 questionnaires to stakeholders who participated in the FDM earlier and received 11 valid responses on 10 October 2020. We employed Super Decision software to derive weights of stakeholder-driven judgments. The formulation of the ANP network structure was set as a network that is interdependent among criterion, sub-criterion, solutions, and the relation between different nodes in a cluster [100]. Lastly, examining the consistency of the stakeholder-driven judgments by intending the consistency ratio (CR) calculation aims to illustrate the confidence level of the judgments for each pairwise comparison. If $\mathrm{CR}$ has a value from 0 to 0.1 , the judgment is accepted; otherwise, prejudgment is needed [101].

\subsection{Mapping Flood Hazard, Flood Vulnerability, and Flood Risk}

A flood hazard map was created based on the natural condition layers, and a flood vulnerability map was constructed from both standardized human development and land use management layers. According to the inhomogeneous essence of each indicator, each spatial layer must be standardized after generated. In order to effortlessly compare the data, it is better to set them dimensionless. Thus, parameters relating to the natural condition, human development, and land use management were normalized in the range of $0-1$ $(0=$ the minimum intensity, one $=$ maximum intensity) [102]. The standardization process objectively enhances the validation of the approach [103]. Each layer was normalized in this study based on the direct or inverse function of flood-related relationships [41]. Each 
layer is weighted and normalized for each indicator to demonstrate the spatial variations of flood intensity across HCMC. The priority-based weight $(\mathrm{W})$ generated through ANP was automatically calculated by the Super Decision software. The normalized $(\mathrm{N})$ rankings of the number $(\mathrm{n})$ of hazard indicators $(\mathrm{H})$ or vulnerability indicators $(\mathrm{V})$ together were used to compute the hazard intensity (formula 1) and vulnerability intensity (formula 2) [41,104] for each pixel via the Raster Calculator tool in ArcGIS. Flood hazard and vulnerability were calculated as the following: $\mathrm{N}_{\mathrm{H}(\mathrm{n})}$

(1) Hazard intensity $=\mathrm{W}_{\mathrm{H}(1)} \times \mathrm{N}_{\mathrm{H}(1)}+\mathrm{W}_{\mathrm{H}(2)} \times \mathrm{N}_{\mathrm{H}(2)}+\mathrm{W}_{\mathrm{H}(3)} \times \mathrm{N}_{\mathrm{H}(3)}+\ldots \mathrm{W}_{\mathrm{H}(\mathrm{n})} \times$

(2) Vulnerability intensity $=\mathrm{W}_{\mathrm{V}(1)} \times \mathrm{N}_{\mathrm{V}(1)}+\mathrm{W}_{\mathrm{V}(2)} \times \mathrm{N}_{\mathrm{V}(2)}+\mathrm{W}_{\mathrm{V}(3)} \times \mathrm{N}_{\mathrm{V}(3)}+\ldots \mathrm{W}_{\mathrm{V}(\mathrm{n})}$ $\times \mathrm{N}_{\mathrm{V}(\mathrm{n})}$

Finally, both composite scores of flood hazard and flood vulnerability were combined to generate the flood risk intensity $[41,105]$ using the following formula:

(3) Risk intensity $=$ Hazard intensity $\times$ Vulnerability intensity.

\section{Results}

\subsection{Fuzzy Delphi Method}

The results from the qualitative evaluation show that the bottom three least important indicators to assess urban floods in HCMC are the forest areas (78.57\%), loss of agricultural lands $(78.57 \%)$, and loss of forest areas (71.43\%) (Table 2). Other indicators account for $92.86 \%$ and $100 \%$ importance by stakeholders' judgment. In terms of quantitative assessment, three out of thirteen indicators have a verification value less than 0: population growth rate, forest areas, and loss of forest areas. Accordingly, indicators that have the verification value of the project less than 0 represent a divergence in the stakeholders' opinion and therefore are deleted [75]. The fuzzy linguistic scale determines the threshold value. The user's preferences can influence the number of relevant parameters chosen from the evaluation results using the fuzzy Delphi approach. We decided on a low threshold to increase the number of indicators to be included [106]. This selection can increase the efficiency of the assessment purpose and the representativeness of the indicators [107]. Finally, we determined the threshold through an arithmetic mean of stakeholders' consensus value (7.06) multiplied by $90 \%$ to reach 6.36 . Consequently, nine indicators are selected: elevation, slope, distance to river, heavy rainfall, tidal level, population density, distance to dike system, agricultural lands, and loss of water bodies.

Table 2. The results of Fuzzy Delphi Method questionnaire-Criteria index.

\begin{tabular}{|c|c|c|c|c|c|c|c|c|c|c|c|c|c|}
\hline \multirow{2}{*}{ Evaluation Index } & \multicolumn{2}{|c|}{$\begin{array}{c}\text { Conservative } \\
\text { Cognitive } \\
\text { Value }\end{array}$} & \multicolumn{2}{|c|}{$\begin{array}{l}\text { Optimistic } \\
\text { Cognitive } \\
\text { Value }\end{array}$} & \multicolumn{2}{|c|}{ Best Value } & \multicolumn{3}{|c|}{$\begin{array}{l}\text { Geometric } \\
\text { Mean }\end{array}$} & $M^{i}=$ & $Z^{i}=$ & \multirow{2}{*}{$\begin{array}{c}\begin{array}{c}\text { Verification } \\
\text { Value }\end{array} \\
M^{i}-Z^{i}\end{array}$} & \multirow{2}{*}{$\begin{array}{c}\begin{array}{c}\text { Stakeholders } \\
\text { Consensus } \\
\text { Value }\end{array} \\
G^{i}=\left(C^{i}{ }_{M}+\right. \\
\left.O_{M}^{i}\right) / 2 \\
\end{array}$} \\
\hline & $C_{L}^{i}$ & $C^{i} u$ & $O_{L}^{i}$ & $O_{u}^{i}$ & $a_{L}^{i}$ & $a^{i} u$ & $C_{M}^{i}$ & $O_{M}^{i}$ & $a_{M}^{i}$ & $O^{i}{ }_{M}-C^{i}{ }_{M}$ & $C^{i}{ }_{U}-O_{L}^{i}$ & & \\
\hline Elevation & 3 & 8 & 6 & 10 & 7 & 10 & 5.18 & 8.98 & 8.48 & 3.81 & 2 & 1.81 & 7.08 \\
\hline Slope & 2 & 8 & 6 & 10 & 6 & 9 & 5.09 & 8.24 & 7.63 & 3.15 & 2 & 1.15 & 6.67 \\
\hline Distance to river & 2 & 10 & 9 & 10 & 8 & 10 & 5.84 & 9.45 & 8.83 & 3.60 & 1 & 2.60 & 7.65 \\
\hline Heavy rainfall & 4 & 9 & 8 & 10 & 7 & 10 & 6.35 & 8.97 & 8.26 & 2.62 & 1 & 1.62 & 7.66 \\
\hline Tidal level & 2 & 10 & 8 & 10 & 7 & 10 & 5.66 & 9.18 & 8.66 & 3.52 & 2 & 1.52 & 7.42 \\
\hline Population density & 4 & 9 & 7 & 10 & 6 & 9 & 5.91 & 8.38 & 7.78 & 2.47 & 2 & 0.47 & 7.14 \\
\hline Population growth rate & 3 & 10 & 7 & 10 & 6 & 10 & 5.81 & 8.77 & 7.99 & 2.97 & 3 & -0.03 & 7.29 \\
\hline Distance to dike system & 2 & 10 & 7 & 10 & 6 & 10 & 5.66 & 8.95 & 8.28 & 3.29 & 3 & 0.29 & 7.30 \\
\hline Forest areas * & 2 & 10 & 5 & 10 & 3 & 10 & 4.83 & 8.05 & 6.81 & 3.22 & 5 & -1.78 & 6.44 \\
\hline Agricultural lands & 3 & 8 & 6 & 9 & 5 & 8 & 5.33 & 8.02 & 6.70 & 2.69 & 2 & 0.69 & 6.67 \\
\hline Loss of water bodies & 5 & 9 & 8 & 10 & 6 & 10 & 6.57 & 9.27 & 8.30 & 2.70 & 1 & 1.70 & 7.92 \\
\hline Loss of agricultural lands * & 1 & 8 & 5 & 10 & 4 & 9 & 4.12 & 7.26 & 6.55 & 3.14 & 3 & 0.14 & 5.69 \\
\hline Loss of forest areas * & 2 & 9 & 4 & 10 & 3 & 9 & 4.02 & 7.29 & 6.47 & 3.26 & 5 & -1.74 & 5.65 \\
\hline
\end{tabular}

${ }^{*}$ means criteria judged to be important by less than $80 \%$ of stakeholders. 


\subsection{Analytic Network Process}

The results of the comparative relevance analysis of criteria show the relative weight scores A for land use management (0.444), human development (0.370), and natural condition (0.185) (Table 3). The relative weight scores B for nine elements used in subcriteria highlighted that the highest score (0.500) is given population density, distance to dike system, agricultural lands, and loss of water bodies within the assessment parameters in Hierarchy II, followed by agricultural lands (0.222). Then, the overall weight coefficients were calculated by multiplying A and B, accounting for the stakeholders' judgments. The value of the overall weight coefficient also illustrates that the loss of water bodies and agricultural lands are critical indicators for flood risk mapping. Distance to the dike system (0.185) and population density (0.185) are two highly ranked sub-criteria in the human development category. Heavy rainfall (0.042), distance to river (0.041), elevation (0.039), tidal level (0.037), and slope (0.027) are ranked highly in the criteria natural condition category.

Table 3. The overall weights of the scheme strategy under criteria for the evaluation.

\begin{tabular}{|c|c|c|c|c|c|}
\hline Criteria & Relative Weight (A) & Sub-Criteria & Relative Weight (B) & $\begin{array}{l}\text { Overall Weight } \\
\quad(\mathbf{A} \times \mathbf{B})\end{array}$ & $\begin{array}{c}\text { Final Weight } \\
(A \times B \times S)\end{array}$ \\
\hline \multirow{5}{*}{ Natural condition } & \multirow{5}{*}{0.185} & Elevation & 0.211 & 0.039 & 0.018 \\
\hline & & Slope & 0.146 & 0.027 & 0.013 \\
\hline & & Distance to river & 0.219 & 0.041 & 0.019 \\
\hline & & Heavy rainfall & 0.226 & 0.042 & 0.020 \\
\hline & & Tidal level & 0.198 & 0.037 & 0.017 \\
\hline \multirow{2}{*}{ Human development } & \multirow{2}{*}{0.370} & Population density & 0.500 & 0.185 & 0.088 \\
\hline & & Distance to dike system & 0.500 & 0.185 & 0.088 \\
\hline \multirow{2}{*}{$\begin{array}{c}\text { Land use } \\
\text { management }\end{array}$} & \multirow{2}{*}{0.444} & Agricultural lands & 0.500 & 0.222 & 0.105 \\
\hline & & Loss of water bodies & 0.500 & 0.222 & 0.105 \\
\hline
\end{tabular}

The relative weight (S) for drainage system improvement (0.473) is the highest among the three proposed projects that stakeholders judged highly as a strategy for mitigating urban floods. Therefore, this strategy was chosen in this study to map the flood risk. The final weight coefficient $(\mathrm{A} \times \mathrm{B} \times \mathrm{S})$ of overall weights for nine sub-criteria associated with drainage system improvement ranked from the most to the least are loss of water bodies (0.105), agricultural lands (0.105), distance to dike system (0.088), population density (0.088), heavy rainfall (0.020), distance to river (0.019), elevation (0.018), tidal level (0.017), and slope (0.013).

\subsection{Flood Hazard Distribution}

In HCMC, the variation of hazard intensity varies from west to east (Figure 3). Accordingly, in the eastern region, an area of $254.9 \mathrm{~km}^{2}$ covering districts of 2, 9, Thu Duc, and Binh Thanh are shown to be highly exposed to flood hazard with an intensity value ranging from 0.063 to 0.075 . Specifically, the Saigon River and Dong Nai River have the highest exposure to floods (0.088). This area is located in a low-lying terrain, surrounded by steep slopes in the west and northeast, alongside the large river basins, and remarkably observed extreme precipitation. In contrast, the flood hazard intensity is moderate (ranging from 0.051 to 0.063 ) in the city center together with the Can Gio district in the southeast, covering $957.9 \mathrm{~km}^{2}$. The hazard intensity gradually decreases toward western areas. More than $41.4 \%$ of the city area in the north and northwest of the city illustrates low to very low hazard intensity (decreasing from 0.051 to 0.019 ), whereby the northern side of the $\mathrm{Cu} \mathrm{Chi}$ district and western side Binh Chanh district are very low hazard-prone. 


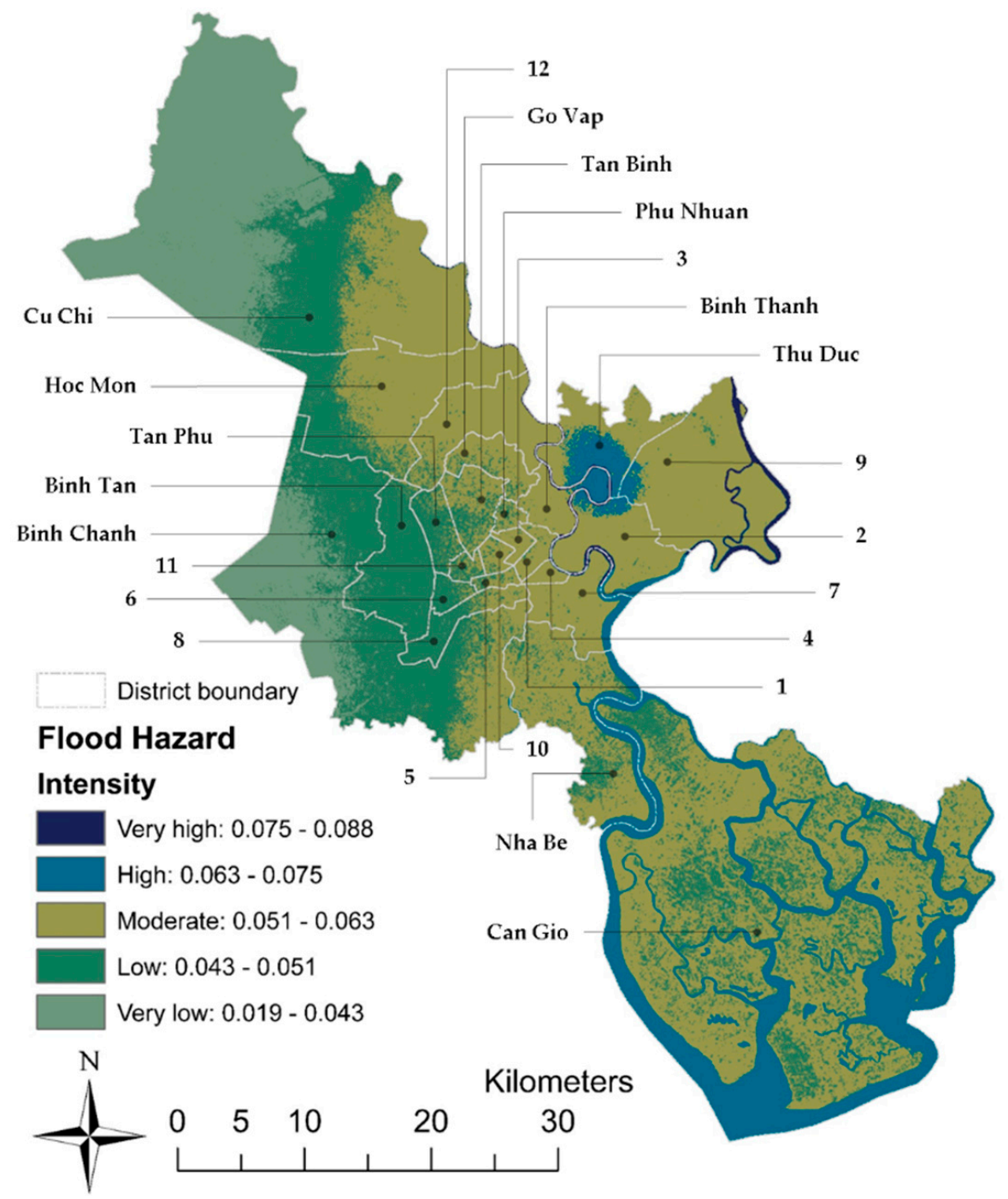

Figure 3. The spatial distribution of flood hazard in HCMC.

\subsection{Flood Vulnerability Distribution}

The flood vulnerability intensity score of the city in HCMC reflects coupled naturehuman indicators such as population density, distance to dikes, agricultural lands, and loss of natural water bodies, which collectively intensify the extent of vulnerability. Areas that are shown as very high vulnerability are associated with the high population density (over 30,000 inhabitants $/ \mathrm{km}^{2}$ ), and the high urban development construction density is highly prone to flood vulnerability. Central districts $(1,3,4,5,6,8,10$, 11, Binh Tan, Tan Phu, Tan Binh, Go Vap, Binh Thanh, Phu Nhuan), covering $12.8 \%$ area or $270.5 \mathrm{~km}^{2}$ of the city area), show a very high vulnerability intensity (0.385) (Figure 4$)$. The growing population in the city's urbanization process leads to the expansion of impervious surfaces in built-up regions [2], and ultimately increases vulnerability to floods [63]. Districts of 2, 7, 9, 12, and Thu Duc in the eastern city in addition to Can Gio mangrove forest, accounting for $39.9 \%$ of the city area, have moderate-high intensity (ranging between 0.169 and 0.269 ) due to the fact that those urban districts had a significant urban expansion earlier from 2010 to 2018, and the mangroves are vulnerable to high tide from the South China Sea. In contrast, the north (Cu Chi district), northwest (Hoc Mon district), and west (Binh Chanh district) parts of the city are primarily agricultural lands that are in close proximity to the dike systems and thus have low to very low flood vulnerability (0.169 to 0$)$. 


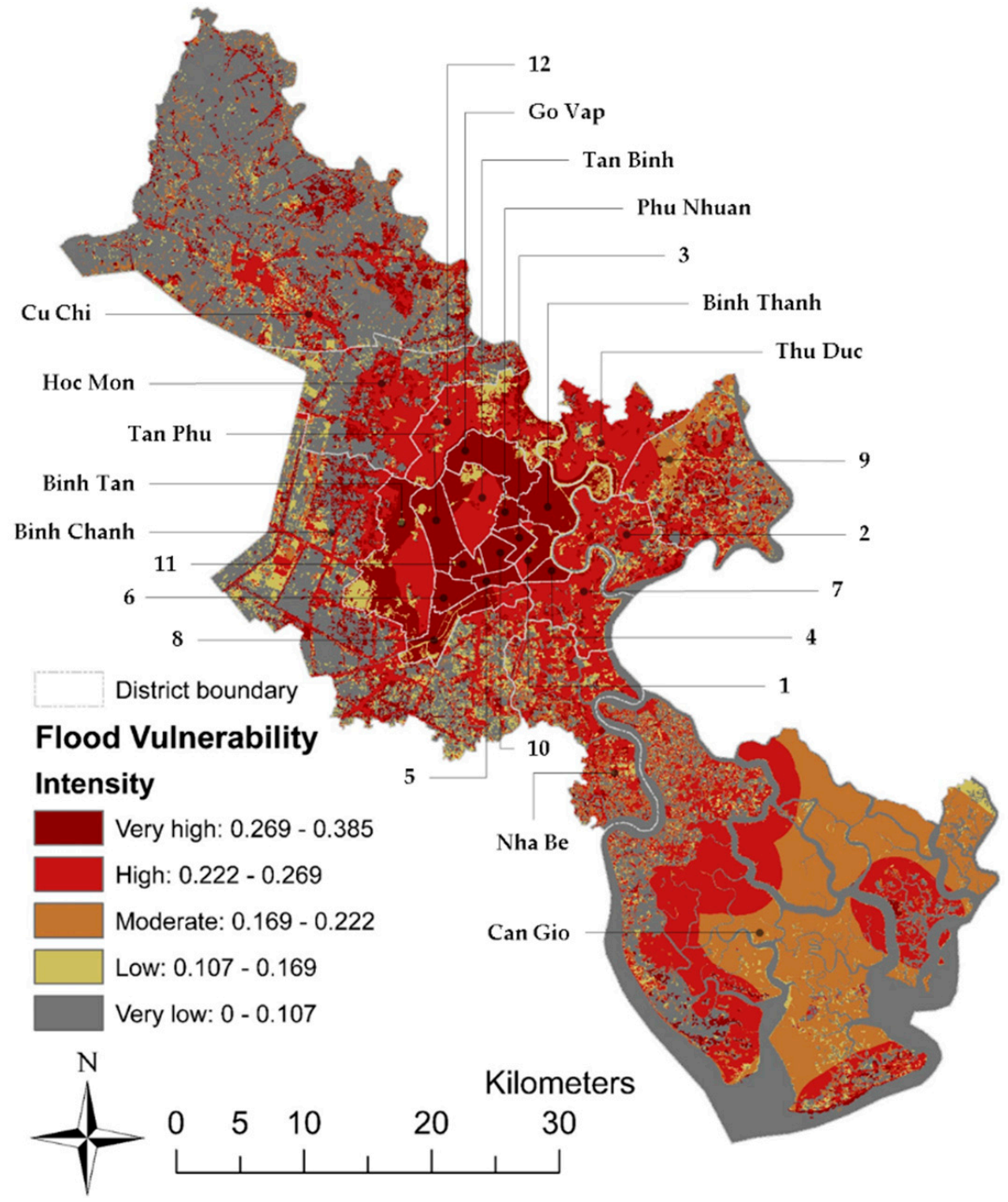

Figure 4. The spatial distribution of flood vulnerability in HCMC.

\subsection{Flood Risk Distribution}

Five levels of flood risk intensity are relatively equally distributed in every direction of the city (Figure 5). The very high intensity of flood risk (ranging between 0.014 and 0.030 ), an area of $229.3 \mathrm{~km}^{2}$, is mostly in the central and northeast of HCMC (districts 1, 3, 4, 5, 6, 10, 11, Go Vap, Thu Duc, Binh Thanh, Phu Nhuan). About $24.1 \%$ of the city illustrates similar flood risk intensity in districts 9, 2, 7, 8, Binh Tan, Tan Binh, Tan Phu, and Nha Be (ranging between 0.012 and 0.014). Cu Chi, Binh Chanh, Hoc Mon, and Can Gio districts show more diverse patterns of flood risk intensity. High-risk areas are in close proximity to the built-up areas, whereas elevated, undulating interfluve zones show varying moderate to very low risks. The moderate flood risk ranges between 0.008 and 0.012 , an area of $381.2 \mathrm{~km}^{2}$, which is distributed mainly in the Can Gio district. In reverse, $46.9 \%\left(989.7 \mathrm{~km}^{2}\right)$ of the city area is in low to very low flood risk (from 0.008 to 0 ). The northern and western areas show less flood risk than the surrounding areas. Overall, the results show that 19 out of 24 administrative districts have high and very high intensity of flood risk. 


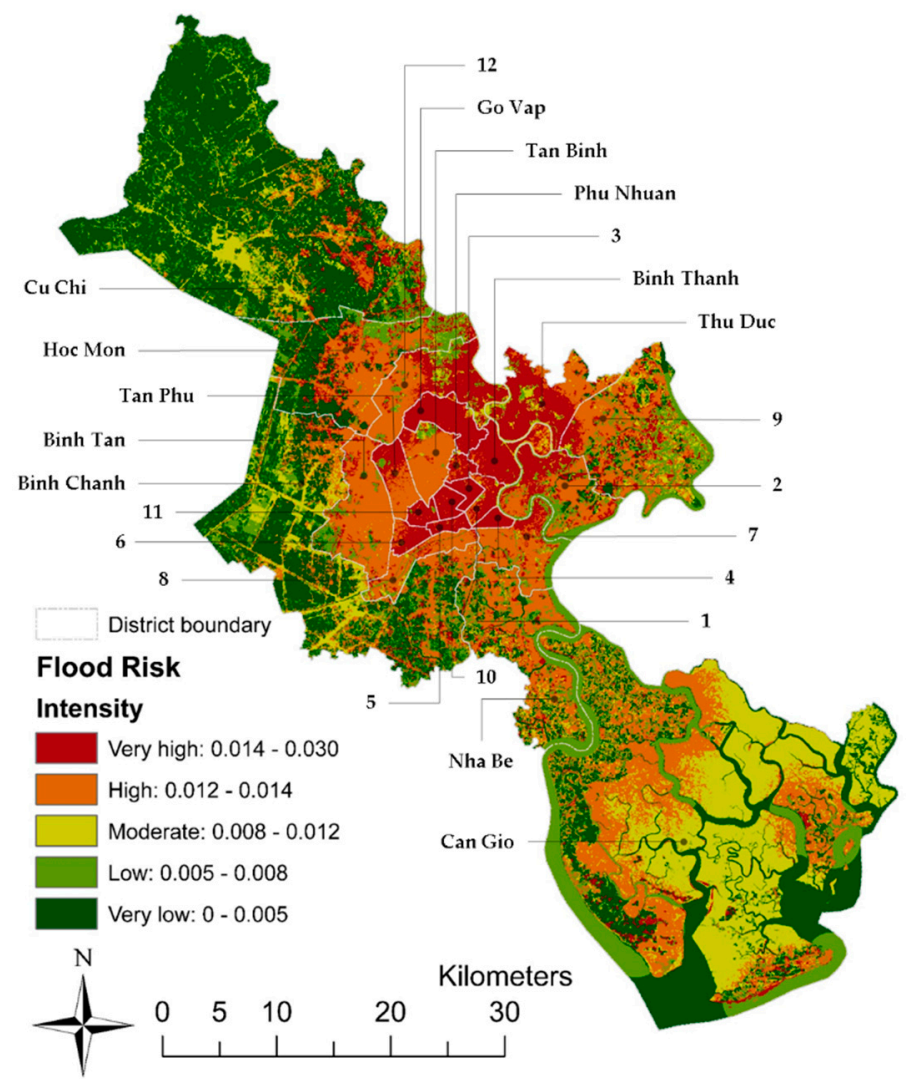

Figure 5. The spatial distribution of flood risk in HCMC.

\section{Discussion}

\subsection{Contribution to Flood Assessment Methods}

In-depth knowledge from experts has indicated that flooding in HCMC causes congestion in transportation, environmental pollution, and economic slowdowns, impacting significantly the health and livelihoods of city residents. Flood risk mapping plays a critical role in the first phase of planning and designing flood control plans and allocating flood protection as well as predictive and warning infrastructures. This study contributes to flood assessment methods by conducting a social survey and integrate stakeholders' knowledge and values judgments through advanced FDM, which resulted in a value representing the consensus of stakeholders based on both quantitative and qualitative evaluations. Based on the gray zone of triangular fuzzy number [75], a tentative conclusion about the usability standards was reached. The results suggest that the obtained indicators have high validity and reliability. As an enhancement to current risk management methodologies using AHP $[41,55,108]$, the study reveals an approach to flood risk studies focused on the ANP $[109,110]$. In addition, the study integrates indicators in coupled nature-human systems and uses ANP-based weights to standardize the ranked indicators. The study attempts to logically combine environmental factors in calculating flood hazard severity and social systems in human development and land use characteristics for measuring vulnerability intensity.

\subsection{Correlation between Flood Hazard and Flood Vulnerability Maps}

To investigate whether there is a relationship between flood hazard and vulnerability in this study [111], we conducted a paired comparison of intensity between flood hazard and flood vulnerability. The result illustrates a significant level $(p<0.01)$ of the Pearson correlation coefficient with the value of $r=-0.164$ [112], showing a weak linear correlation [113]. The analysis of inverse correlation indicates that the two individual variables generally move in opposite directions in a statistical relationship. The variables flood 
hazard and flood vulnerability are negatively correlated. As the flood hazard increases in value, flood vulnerability will decrease, and vice versa. It is worth noting that most of the eastern part of the city, including Districts 2 and 9, shown as moderate flood hazard (Figure 3), have high flood vulnerability due to the expansion of built-up areas and a high population density. In addition, the city's western districts maintain from low to very low flood hazard risk, while many areas have relatively high or very high vulnerability (Figure 4).

\subsection{Implications for Climate Justice Planning}

The finding of a flood risk zone is $97.33 \%$ consistent with the record of the frequent and extreme flooded locations in 2018 collected by the HCMC Flood Control Center (Figure 6). These locations were situated in high to very high-risk areas in the city's most vulnerable urban districts. The degree of a disaster affiliated with the waterlogging calamity depends on population density in a particular area from the human development perspective [114]. A total of 19 urban districts are susceptible to flood risk, with the mean intensity ranging from 0.011 to 0.017 . Comparing to a less populous region, residents in a densely populated area would be more considerably impacted by disasters with comparable magnitude [115] Roughly $70.1 \%$ of the city's population (more than 6.3 million people) in those districts could be affected when urban floods occur. Moreover, these districts consist of more than 180,000 entities, which highly hold more than $95 \%$ value of the property belonging to municipal enterprises [116]. The flood risk map assists urban planners to identify a remarkable circumstance for the atrocious effects on social security and the future development of HCMC, which has implications in climate justice planning [20]. Consequently, the flood risk assessment framework established in this study can be used to identify the most vulnerable populations exposed to urban floods, who are likely to suffer more from climate change impacts. Those climate justice hotspots should be given the highest priority for safety planning, practical actions, and early intervention projects to protect residents from damages under urban flood events. The study demonstrates a negative correlation between flood hazard and flood vulnerability, implying that there is a potential to reduce flood risks and damages when high flood-prone areas are not exposed to highly vulnerable populations.

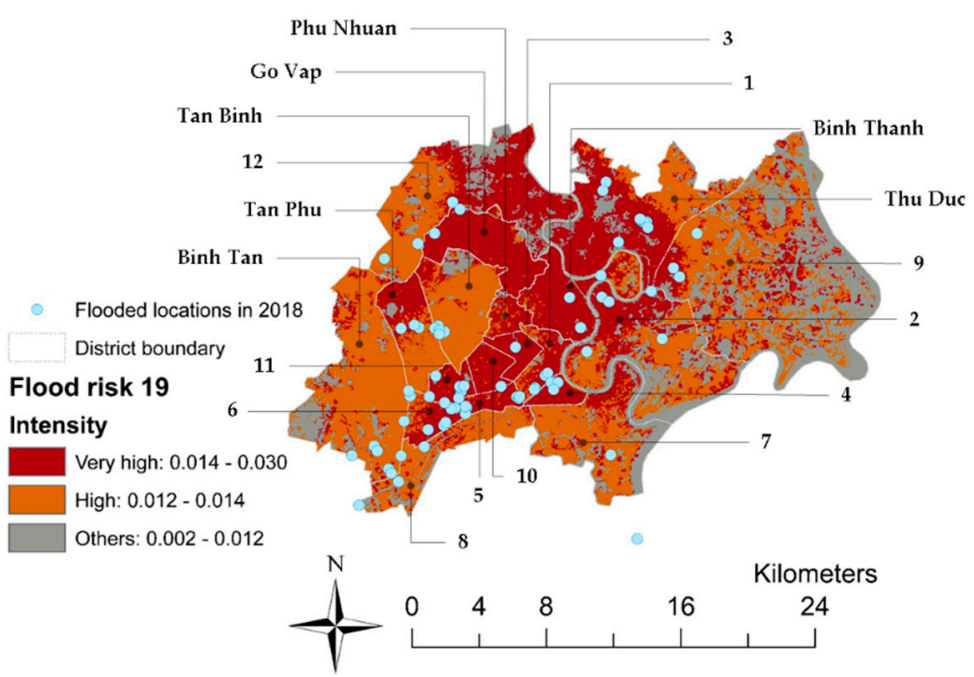

Figure 6. The spatial distribution of actual flooded locations in 2018.

\subsection{Implications for Urban Resilience Strategies}

Flood disasters often traumatize society in Vietnam. Reducing economic losses and enhancing urban resilience play a critical role in the sustainable development of HCMC. The governmental authorities together with civil society organizations shall work hand-in-hand in sustainable development programs to exacerbate synergies and institute strategies for 
implementing transformative changes to enhance urban resilience. A robust intervention would not only enable flood mitigation but ensure that development achievements are sustained in the city. This study demonstrates the value of using a flood risk map to identify sensitive sites for demanding righteous strategies. Most high flood risk areas shown are concentrated along the eastern side of the city, where it can be determined in the central basin of Saigon and Dong Nai River and observed extreme rainfall annually. Many flood management projects have been proposed in HCMC; however, they are often delayed for several years [3]. Our analysis indicates that the governmental project of drainage system improvement is the most important strategy for long-term environmental management aiming to protect urban populations from flood disasters. Alternatively, urban spatial planning can contribute to reducing exposures to multiple hazards through changing urban morphology, reducing vulnerability, and enhancing urban resilience [117]. For example, preserving and restoring natural vegetation landscapes would reduce vulnerability to floods $[118,119]$. In addition, other approaches, including utilizing aquaculture areas as water retention ponds, building pumping stations, and constructing flood diversion culverts, are also considered as effective urban resilience strategies in a recent study by Chang et al. 2020 with the case of Tuku lowlands in Taiwan [120]. Finally, transdisciplinary collaborations between governmental organizations, stakeholders, scientists, engineers, planners, designers, etc., that at all stages closely work with communities to co-develop place-based strategies that reflect complex coupled nature-human systems are crucial for building urban resilience and sustainability [117,121].

\section{Conclusions}

Years of flood events have wreaked havoc on the lower Saigon River flood plain. The damage that occurred in flood events emphasized the importance of risk management to understand better the social-ecological systems associated with floods. Flood risk management embraces a broad range of strategies from the forecast of flood hazards and vulnerabilities to the social effects and risk-reduction measures and tools [44,122]. Flood risks assessment considers dynamics in the interconnected social-ecological-technological systems across temporal and spatial scales [112] and identifies a climate justicescape [20]. This study proposed a coupled nature-human approach that can better inform risk management and enhances urban resilience toward sustainable development pathways [33,34]. The quantitative and qualitative evaluation of flood risk is essential in regional planning and catastrophe preparedness [110]. The aggregate impact estimation of many vital parameters in urban flood management aims to plan and improve urban infrastructure for resilience, impacting climate change in the future [123-125]. Identifying flood-prone areas is a critical and significant component of emergency prevention for any regions seeking to monitor and mitigate the effects of preventing urban flood damage [51,103].

The implementation of urban flood risk management in climate justice areas has become the top priority in building resilient cities [34,126-128]. In the case of HCMC, areas dominated by elevation elements, slope flat, low-lying plain, and surrounded rivers are highly risk-prone due to the excessive likelihood of flood events associated with populated concentration, built-up areas extension encompassing almost the entire centre, and northeastern parts of the area HCMC. Consequently, the result of the current study can be accessible in determining variables that boost resilience, which can then be factored into potential flood risk management planning decisions. Furthermore, the implementation of this study can be further conducted, more specifically at a district level along the basins of the Saigon and Dong Nai rivers. This would allow the attempt to generate a more comprehensive risk map for a district to manage the floods of a sensitive region effectively. Finally, the flood risk assessment framework developed in this study can be applied to other regions of the world for identifying vulnerable populations exposed to climate change associated hazards and highlight top priority areas for climate justice planning and policies for urban resilience. 
Author Contributions: Conceptualization, C.-F.W. and L.V.T.T.; methodology C.-F.W.; software, L.V.T.T.; validation, C.-F.W., S.-H.C. and L.V.T.T.; formal analysis, C.-F.W., S.-H.C. and L.V.T.T.; investigation, C.-F.W. and L.V.T.T.; resources, L.V.T.T.; data curation, L.V.T.T.; writing-original draft preparation, C.-F.W., S.-H.C., C.-W.C. and L.V.T.T.; writing-review and editing, C.-F.W., C.-W.C. and L.V.T.T.; visualization, L.V.T.T.; supervision, C.-F.W.; project administration, C.-F.W., S.-H.C. and L.V.T.T.; funding acquisition, C.-F.W. All authors have read and agreed to the published version of the manuscript.

Funding: Ministry of Science and Technology of the Republic of China, Taiwan financially supports parts of this research under Contract No. 109-2621-M-002-008-MY3 and 109-2625-M-005-002-MY2, and MOST 110-2321-B-005-003. The work related to policy communication, environmental education, and outreach was also supported by the "Innovation and Development Center of Sustainable Agriculture" from the Featured Areas Research Center Program within the framework of the Higher Education Sprout Project by the Ministry of Education (MOE) in Taiwan.

Institutional Review Board Statement: Not applicable.

Informed Consent Statement: Not applicable.

Data Availability Statement: Data sharing not applicable. No new data were created or analyzed in this study. Data sharing is not applicable to this article.

Acknowledgments: The authors would like to warmly thank the Ministry of Science and Technology and Ministry of Education (MOE) in Taiwan for funding support. We are incredibly thankful to experts in universities and research institutes for participating in the surveys. We express sincere appreciation to The Center for Hydro-Meteorological Data, The Institute of Coastal and Offshore Engineering, The Branch of Water Resources HCMC, and Nong Lam University HCMC in Vietnam for providing original data.

Conflicts of Interest: The authors declare no conflict of interest. The funders had no role in the design of the study; in the collection, analyses, or interpretation of data; in the writing of the manuscript; or in the decision to publish the results.

\section{References}

1. Kontgis, C.; Schneider, A.; Fox, J.; Saksena, S.; Spencer, J.H.; Castrence, M. Monitoring peri-urbanization in the greater Ho Chi Minh City metropolitan area. Appl. Geogr. 2014, 53, 377-388. [CrossRef]

2. Son, N.-T.; Chen, C.-F.; Chen, C.-R.; Thanh, B.-X.; Vuong, T.-H. Assessment of urbanization and urban heat islands in Ho Chi Minh City, Vietnam using Landsat data. Sustain. Cities Soc. 2017, 30, 150-161. [CrossRef]

3. Huynh, D. The misuse of urban planning in Ho Chi Minh City. Habitat Int. 2015, 48, 11-19. [CrossRef]

4. Gigović, L.; Pamučar, D.; Bajić, Z.; Drobnjak, S. Application of GIS-Interval Rough AHP Methodology for Flood Hazard Mapping in Urban Areas. Water 2017, 9, 360. [CrossRef]

5. Mentens, J.; Raes, D.; Hermy, M. Green roofs as a tool for solving the rainwater runoff problem in the urbanized 21st century? Landsc. Urban Plan. 2006, 77, 217-226. [CrossRef]

6. Didenko, N.; Skripnuk, D.; Mirolyubova, O. Urbanization and greenhouse gas emissions from industry. IOP Conf. Ser. Earth Environ. Sci. 2017, 72, 012014. [CrossRef]

7. Holden, W.N. Endogenous exacerbation of an exogenous problem: Climate change, environmental degradation, and unsustainable development practices in the Philippines. Asian Geogr. 2019, 36, 1-27. [CrossRef]

8. Sarvari, H. A survey of relationship between urbanization and climate change for major cities in Iran. Arab. J. Geosci. 2019, 12, 1-10. [CrossRef]

9. Ahmadalipour, A.; Moradkhani, H.; Castelletti, A.; Magliocca, N. Future drought risk in Africa: Integrating vulnerability, climate change, and population growth. Sci. Total Environ. 2019, 662, 672-686. [CrossRef]

10. Frame, D.J.; Wehner, M.F.; Noy, I.; Rosier, S.M. The economic costs of Hurricane Harvey attributable to climate change. Clim. Chang. 2020, 160, 271-281. [CrossRef]

11. Hettiarachchi, S.; Wasko, C.; Sharma, A. Increase in flood risk resulting from climate change in a developed urban watershed-the role of storm temporal patterns. Hydrol. Earth Syst. Sci. 2018, 22, 2041-2056. [CrossRef]

12. Hirabayashi, Y.; Mahendran, R.; Koirala, S.; Konoshima, L.; Yamazaki, D.; Watanabe, S.; Kim, H.; Kanae, S. Global flood risk under climate change. Nat. Clim. Chang. 2013, 3, 816-821. [CrossRef]

13. Kang, S.; Eltahir, E.A. North China Plain threatened by deadly heatwaves due to climate change and irrigation. Nat. Commun. 2018, 9, 1-9. [CrossRef]

14. Olesen, J.E.; Bindi, M. Consequences of climate change for European agricultural productivity, land use and policy. Eur. J. Agron. 2002, 16, 239-262. [CrossRef]

15. Rahmstorf, S. A new view on sea level rise. Nat. Clim. Chang. 2010, 1, 44-45. [CrossRef] 
16. Vu, D.; Yamada, T.; Ishidaira, H. Assessing the impact of sea level rise due to climate change on seawater intrusion in Mekong Delta, Vietnam. Water Sci. Technol. 2018, 77, 1632-1639. [CrossRef]

17. Cheng, C.; Yang, Y.C.E.; Ryan, R.; Yu, Q.; Brabec, E. Assessing climate change-induced flooding mitigation for adaptation in Boston's Charles River watershed, USA. Landsc. Urban Plan. 2017, 167, 25-36. [CrossRef]

18. Fernandez, D.; Lutz, M. Urban flood hazard zoning in Tucumán Province, Argentina, using GIS and multicriteria decision analysis. Eng. Geol. 2010, 111, 90-98. [CrossRef]

19. Cheng, C. Spatial climate justice and green infrastructure assessment: A case for the Huron River watershed, Michigan, USA. GI Forum 2016, 1, 179-190. [CrossRef]

20. Cheng, C. Climate Justicescape and Implications for urban Resilience in American Cities. In The Routledge Handbook of Urban Resilience; Burayidi, M., Twigg, J., Allen, A., Wamlester, C., Eds.; Routledge, Taylor \& Francis Books: New York, NY, USA, 2019; pp. 83-96.

21. Huong, H.T.L.; Pathirana, A. Urbanization and climate change impacts on future urban flooding in Can Tho city, Vietnam. Hydrol. Earth Syst. Sci. 2013, 17, 379-394. [CrossRef]

22. Ishigaki, T.; Kawanaka, R.; Onishi, Y.; Shimada, H.; Toda, K.; Baba, Y. Assessment of safety on evacuating route during underground flooding. In Advances in Water Resources and Hydraulic Engineering; Springer: Berlin/Heidelberg, Germany, 2009; pp. 141-146. [CrossRef]

23. Tran Ngoc, T.D.; Perset, M.; Strady, E.; Phan, T.S.H.; Vachaud, G.; Quertamp, F.; Gratiot, N. Ho Chi Minh City growing with water related challenges. In Water, Megacities and Global Change: Portraits of 15 Emblematic Cities of the World; UNESCO; ARCEAU: Paris, France, 2016; p. 27.

24. Vachaud, G.; Quertamp, F.; Phan, T.S.H.; Ngoc, T.D.T.; Nguyen, T.; Luu, X.L.; Nguyen, A.T.; Gratiot, N. Flood-related risks in Ho Chi Minh City and ways of mitigation. J. Hydrol. 2019, 573, 1021-1027. [CrossRef]

25. Nguyen, D. Size, Shape and Dispersion: Urban form evolution in Saigon River Basin and its impacts on hydrologic performance from 1990 to 2010. In Proceedings of the 49th ISOCARP Congress, Brisbane, Australia, 1-4 October 2013; p. 12.

26. Asian Development Bank. Available online: https://www.adb.org/publications/ho-chi-minh-city-adaptation-climate-changesummary-report (accessed on 6 February 2020).

27. Ministry of Transportation. Available online: https://mt.gov.vn/moitruong/tin-tuc/993/58230/tp-hcm-dang-chiu-thiet-haihon-1-500-ty-dong-moi-nam-do-ngap-nuoc.aspx (accessed on 6 February 2020).

28. Rehman, J.; Sohaib, O.; Asif, M.; Pradhan, B. Applying systems thinking to flood disaster management for a sustainable development. Int. J. Disaster Risk Reduct. 2019, 36, 101101. [CrossRef]

29. Babut, M.; Mourier, B.; Desmet, M.; Simonnet-Laprade, C.; Labadie, P.; Budzinski, H.; De Alencastro, L.F.; Tu, T.A.; Strady, E.; Gratiot, N. Where has the pollution gone? A survey of organic contaminants in Ho Chi Minh city/Saigon River (Vietnam) bed sediments. Chemosphere 2019, 217, 261-269. [CrossRef]

30. Lee, S.K.; Dang, T.A.; Tran, T.H. Combining rainfall-runoff and hydrodynamic models for simulating flow under the impact of climate change to the lower Sai Gon-Dong Nai River basin. Paddy Water Environ. 2018, 16, 457-465. [CrossRef]

31. Rosenzweig, B.R.; McPhillips, L.; Chang, H.; Cheng, C.; Welty, C.; Matsler, M.; Iwaniec, D.; Davidson, C.I. Pluvial flood risk and opportunities for resilience. WIREs Water 2018, 5, e1302. [CrossRef]

32. Office of the People's Committee in Kon Tum Province. Available online: http:/ / kontumvpub.gov.vn/NewsDetail.aspx?id=295 (accessed on 6 February 2020).

33. Nawaz, A.; Waqar, A.; Shah, S.A.R.; Sajid, M.; Khalid, M.I. An Innovative Framework for Risk Management in Construction Projects in Developing Countries: Evidence from Pakistan. Risks 2019, 7, 24. [CrossRef]

34. Nkwunonwo, U.C.; Whitworth, M.; Baily, B. A review of the current status of flood modelling for urban flood risk management in the developing countries. Sci. Afr. 2020, 7, e00269. [CrossRef]

35. Hazarika, N.; Barman, D.; Das, A.K.; Sarma, A.K.; Borah, S.B. Assessing and mapping flood hazard, vulnerability and risk in the Upper Brahmaputra River valley using stakeholders' knowledge and multicriteria evaluation (MCE). J. Flood Risk Manag. 2018, 11, S700-S716. [CrossRef]

36. Hudson, P.; Botzen, W.J.W.; Kreibich, H.; Bubeck, P.; Aerts, J. Evaluating the effectiveness of flood damage mitigation measures by the application of propensity score matching. Nat. Hazards Earth Syst. Sci. 2014, 14, 1731-1747. [CrossRef]

37. Merz, B.; Thieken, A.; Gocht, M. Flood risk mapping at the local scale: Concepts and challenges. In Flood Risk Management in Europe; Begum, S., Stive, M.J.F., Hall, J.W., Eds.; Springer: Dordrecht, The Netherlands, 2007; Volume 25, pp. $231-251$.

38. Tingsanchali, T.; Karim, M.F. Flood hazard and risk analysis in the southwest region of Bangladesh. Hydrol. Process. 2005, 19, 2055-2069. [CrossRef]

39. van Alphen, J.; Martini, F.; Loat, R.; Slomp, R.; Passchier, R. Flood risk mapping in Europe, experiences and best practices. J. Flood Risk Manag. 2009, 2, 285-292. [CrossRef]

40. Das, S. Geographic information system and AHP-based flood hazard zonation of Vaitarna basin, Maharashtra, India. Arab. J. Geosci. 2018, 11, 13. [CrossRef]

41. Ghosh, A.; Kar, S.K. Application of analytical hierarchy process (AHP) for flood risk assessment: A case study in Malda district of West Bengal, India. Nat. Hazards 2018, 94, 349-368. [CrossRef]

42. Seejata, K.; Yodying, A.; Wongthadam, T.; Mahavik, N.; Tantanee, S. Assessment of flood hazard areas using analytical hierarchy process over the Lower Yom Basin, Sukhothai Province. Procedia Eng. 2018, 212, 340-347. [CrossRef] 
43. Stefanidis, S.; Stathis, D. Assessment of flood hazard based on natural and anthropogenic factors using analytic hierarchy process (AHP). Nat. Hazards 2013, 68, 569-585. [CrossRef]

44. Messner, F.; Meyer, V. Flood Damage, Vulnerability and Risk Perception-Challenges for Flood Damage Research. In Flood Risk Management: Hazards, Vulnerability and Mitigation Measures; Springer: Dordrecht, The Netherlands, 2006; Volume 67, pp. 149-167.

45. Danumah, J.H.; Odai, S.N.; Saley, B.M.; Szarzynski, J.; Thiel, M.; Kwaku, A.; Kouame, F.K.; Akpa, L.Y. Flood risk assessment and mapping in Abidjan district using multicriteria analysis (AHP) model and geoinformation techniques, (cote d'ivoire). Geoenvironment. Disasters 2016, 3, 1-13. [CrossRef]

46. Portal of the Ministry of Construction. Available online: https://moc.gov.vn/tl/tin-tuc/63149/tp-ho-chi-minh-dieu-chinh-quyhoach-thoat-nuoc--mo-rong-tren-dien-tich-2-095km2.aspx (accessed on 6 February 2020).

47. Party Committee of Ho Chi Minh City. Available online: https://hcmcpv.org.vn/tin-tuc/tphcm-mot-so-du-an-chong-ngap-ungdua-vao-su-dung-phat-huy-hieu-qua-1491873572 (accessed on 6 February 2021).

48. Leitao, J.P.; de Sousa, L.M. Towards the optimal fusion of high-resolution Digital Elevation Models for detailed urban flood assessment. J. Hydrol. 2018, 561, 651-661. [CrossRef]

49. Rahmati, O.; Darabi, H.; Haghighi, A.T.; Stefanidis, S.; Kornejady, A.; Nalivan, O.A.; Tien Bui, D. Urban Flood Hazard Modeling Using Self-Organizing Map Neural Network. Water 2019, 11, 2370. [CrossRef]

50. Stieglitz, M.; Rind, D.; Famiglietti, J.; Rosenzweig, C. An Efficient Approach to Modeling the Topographic Control of Surface Hydrology for Regional and Global Climate Modeling. J. Clim. 1997, 10, 118-137. [CrossRef]

51. Darabi, H.; Choubin, B.; Rahmati, O.; Haghighi, A.T.; Pradhan, B.; Kløve, B. Urban flood risk mapping using the GARP and QUEST models: A comparative study of machine learning techniques. J. Hydrol. 2019, 569, 142-154. [CrossRef]

52. Pham, B.T.; Avand, M.; Janizadeh, S.; Phong, T.V.; Al-Ansari, N.; Ho, L.S.; Das, S.; Le, H.V.; Amini, A.; Bozchaloei, S.K.; et al. GIS Based Hybrid Computational Approaches for Flash Flood Susceptibility Assessment. Water 2020, 12, 683. [CrossRef]

53. Ouma, Y.O.; Tateishi, R. Urban flood vulnerability and risk mapping using integrated multi-parametric AHP and GIS: Methodological overview and case study assessment. Water 2014, 6, 1515-1545. [CrossRef]

54. Adnan, M.S.G.; Talchabhadel, R.; Nakagawa, H.; Hall, J.W. The potential of Tidal River Management for flood alleviation in South Western Bangladesh. Sci. Total Environ. 2020, 731, 13. [CrossRef] [PubMed]

55. Chen, Y.-R.; Yeh, C.-H.; Yu, B. Integrated application of the analytic hierarchy process and the geographic information system for flood risk assessment and flood plain management in Taiwan. Nat. Hazards 2011, 59, 1261-1276. [CrossRef]

56. Pradhan-Salike, I.; Pokharel, J.R. Impact of urbanization and climate change on urban flooding: A case of the Kathmandu Valley. J. Nat. Resour. Dev. 2016, 7, 56-66. [CrossRef]

57. Abebe, Y.A.; Ghorbani, A.; Nikolic, I.; Vojinovic, Z.; Sanchez, A. A coupled flood-agent-institution modelling (CLAIM) framework for urban flood risk management. Environ. Model. Softw. 2019, 111, 483-492. [CrossRef]

58. Thanh, V.Q.; Roelvink, D.; van der Wegen, M.; Reyns, J.; Kernkamp, H.; Vinh, G.V.; Linh, V.T.P. Flooding in the Mekong Delta: The impact of dyke systems on downstream hydrodynamics. Hydrol. Earth Syst. Sci. 2020, 24, 189-212. [CrossRef]

59. Bradshaw, C.J.A.; Sodhi, N.S.; Peh, K.S.H.; Brook, B.W. Global evidence that deforestation amplifies flood risk and severity in the developing world. Glob. Chang. Biol. 2007, 13, 2379-2395. [CrossRef]

60. Dung, T.T.T.; Linh, T.M.; Chau, T.B.; Hoang, T.M.; Swennen, R.; Cappuyns, V. Contamination status and potential release of trace metals in a mangrove forest sediment in Ho Chi Minh City, Vietnam. Environ. Sci. Pollut. Res. 2019, 26, 9536-9551. [CrossRef]

61. Menéndez, P.; Losada, I.J.; Torres-Ortega, S.; Narayan, S.; Beck, M.W. The Global Flood Protection Benefits of Mangroves. Sci. Rep. 2020, 10, 4404. [CrossRef]

62. Posthumus, H.; Hewett, C.J.M.; Morris, J.; Quinn, P.F. Agricultural land use and flood risk management: Engaging with stakeholders in North Yorkshire. Agric. Water Manag. 2008, 95, 787-798. [CrossRef]

63. Schaefer, M.; Thinh, N.X. Evaluation of land cover change and agricultural protection sites: A GIS and remote sensing approach for Ho chi minh city, vietnam. Heliyon 2019, 5, e01773. [CrossRef] [PubMed]

64. Duy, P.N.; Chapman, L.; Tight, M.; Thuong, L.V.; Linh, P.N. Urban Resilience to Floods in Coastal Cities: Challenges and Opportunities for Ho Chi Minh City and Other Emerging Cities in Southeast Asia. J. Urban Plan. Dev. 2018, 144, 05017018. [CrossRef]

65. Nasiri, H.; Yusof, M.; Ali, T.; Hussein, M. District flood vulnerability index: Urban decision-making tool. Int. J. Environ. Sci. Technol. 2019, 16, 2249-2258. [CrossRef]

66. Sun, H.; Cheng, X.; Dai, M. Regional flood disaster resilience evaluation based on analytic network process: A case study of the Chaohu Lake Basin, Anhui Province, China. Nat. Hazards 2016, 82, 39-58. [CrossRef]

67. Saaty, T.L. The analytic hierarchy and analytic network processes for the measurement of intangible criteria and for decisionmaking. In Multiple Criteria Decision Analysis, 2nd ed.; Greco, S., Ehrgott, M., Figueira, J.R., Eds.; Springer: Berlin/Heidelberg, Germany, 2016; Volume 1, pp. 363-419.

68. Juang, S.-R.; Chen, S.-H.; Wu, C.-F. An Expert-based assessment model for evaluating habitat suitability of pond-breeding amphibians. Sustainability 2017, 9, 278. [CrossRef]

69. Jeng, T. Fuzzy Assessment Model for Maturity of Software Organization in Improving its Staff's Capability. Master's Thesis, National Taiwan University of Science and Technology, Taipei, Taiwan, 2001.

70. Kuo, Y.-F.; Chen, P.-C. Constructing performance appraisal indicators for mobility of the service industries using Fuzzy Delphi Method. Expert Syst. Appl. 2008, 35, 1930-1939. [CrossRef] 
71. Yang, T.; Su, C.T.; Hsu, Y.R. Systematic layout planning: A study on semiconductor wafer fabrication facilities. Int. J. Oper. Prod. Manag. 2000. [CrossRef]

72. Wang, W.-M.; Lee, A.H.; Chang, D.-T. An integrated FDM-ANP evaluation model for sustainable development of housing community. Optim. Lett. 2010, 4, 239-257. [CrossRef]

73. Johnson, T.P. Snowball Sampling: Introduction. In Wiley StatsRef: Statistics Reference Online; Balakrishnan, N., Colton, T., Everitt, B., Piegorsch, W., Ruggeri, F., Teugels, J.L., Eds.; Wiley Online Library: New Jersey, NJ, USA, 2014. [CrossRef]

74. Lai, C.-H.; Lin, S.-H.; Tsai, C.-Y.; Chen, S.-H. Identifying Farm Pond Habitat Suitability for the Common Moorhen (Gallinula chloropus): A Conservation-Perspective Approach. Sustainability 2018, 10, 1352. [CrossRef]

75. Chou, W.-W.; Lee, S.-H.; Wu, C.-F. Evaluation of the Preservation Value and Location of Farm Ponds in Yunlin County, Taiwan. Int. J. Environ. Res. Public Health 2014, 11, 548-572. [CrossRef]

76. Wei, W.L.; Chang, W.C. A study on selecting optimal product design solution using fuzzy Delphi method and analytic. J. Des. 2007, 10, 59-76.

77. Scawthorn, C.; Blais, N.; Seligson, H.; Tate, E.; Mifflin, E.; Thomas, W.; Murphy, J.; Jones, C. HAZUS-MH Flood Loss Estimation Methodology. I: Overview and Flood Hazard Characterization. Nat. Hazards Rev. 2006, 7, 60-71. [CrossRef]

78. Schumann, G.J.P.; Neal, J.C.; Mason, D.C.; Bates, P.D. The accuracy of sequential aerial photography and SAR data for observing urban flood dynamics, a case study of the UK summer 2007 floods. Remote Sens. Environ. 2011, 115, 2536-2546. [CrossRef]

79. Yalcin, E. Assessing the impact of topography and land cover data resolutions on two-dimensional HEC-RAS hydrodynamic model simulations for urban flood hazard analysis. Nat. Hazards 2020, 101, 995-1017. [CrossRef]

80. Hayakawa, Y.S.; Oguchi, T.; Lin, Z. Comparison of new and existing global digital elevation models: ASTER G-DEM and SRTM-3. Geophys. Res. Lett. 2008, 35. [CrossRef]

81. Cabrera, J.S.; Lee, H.S. Impacts of Climate Change on Flood-Prone Areas in Davao Oriental, Philippines. Water 2018, 10, 893. [CrossRef]

82. Cabrera, J.S.; Lee, H.S. Flood risk assessment for Davao Oriental in the Philippines using geographic information system-based multicriteria analysis and the maximum entropy model. J. Flood Risk Manag. 2020, 13, 17. [CrossRef]

83. Huong, D.T.V.; Nagasawa, R. Potential flood hazard assessment by integration of ALOS PALSAR and ASTER GDEM: A case study for the Hoa Chau commune, Hoa Vang district, in central Vietnam. J. Appl. Remote Sens. 2014, 8, 083626. [CrossRef]

84. Wang, Z.L.; Lai, C.G.; Chen, X.H.; Yang, B.; Zhao, S.W.; Bai, X.Y. Flood hazard risk assessment model based on random forest. J. Hydrol. 2015, 527, 1130-1141. [CrossRef]

85. Lima, A.O.; Lyra, G.B.; Abreu, M.C.; Oliveira-Júnior, J.F.; Zeri, M.; Cunha-Zeri, G. Extreme rainfall events over Rio de Janeiro State, Brazil: Characterization using probability distribution functions and clustering analysis. Atmos. Res. 2021, $247,105221$. [CrossRef]

86. Alam, M.A.; Emura, K.; Farnham, C.; Yuan, J. Best-Fit Probability Distributions and Return Periods for Maximum Monthly Rainfall in Bangladesh. Climate 2018, 6, 9. [CrossRef]

87. Beskow, S.; Caldeira, T.L.; de Mello, C.R.; Faria, L.C.; Guedes, H.A.S. Multiparameter probability distributions for heavy rainfall modeling in extreme southern Brazil. J. Hydrol. Reg. Stud. 2015, 4, 123-133. [CrossRef]

88. Nardi, F.; Annis, A.; Biscarini, C. On the impact of urbanization on flood hydrology of small ungauged basins: The case study of the Tiber river tributary network within the city of Rome. J. Flood Risk Manag. 2018, 11, S594-S603. [CrossRef]

89. Nardi, F.; Biscarini, C.; Di Francesco, S.; Manciola, P.; Ubertini, L. Comparing A Large-Scale Dem-Based Floodplain Delineation Algorithm With Standard Flood Maps: The Tiber River Basin Case Study. Irrig. Drain. 2013, 62, 11-19. [CrossRef]

90. Nardi, F.; Grimaldi, S.; Santini, M.; Petroselli, A.; Ubertini, L. Hydrogeomorphic properties of simulated drainage patterns using digital elevation models: The flat area issue/Propriétés hydro-géomorphologiques de réseaux de drainage simulés à partir de modèles numériques de terrain: La question des zones planes. Hydrol. Sci. J. 2008, 53, 1176-1193. [CrossRef]

91. Samela, C.; Manfreda, S.; Paola, F.D.; Giugni, M.; Sole, A.; Fiorentino, M. DEM-Based Approaches for the Delineation of Flood-Prone Areas in an Ungauged Basin in Africa. J. Hydrol. Eng. 2016, 21, 06015010. [CrossRef]

92. Vorogushyn, S.; Lindenschmidt, K.-E.; Kreibich, H.; Apel, H.; Merz, B. Analysis of a detention basin impact on dike failure probabilities and flood risk for a channel-dike-floodplain system along the river Elbe, Germany. J. Hydrol. 2012, 436, 120-131. [CrossRef]

93. Wang, Y.; Li, Z.; Tang, Z.; Zeng, G. A GIS-based spatial multicriteria approach for flood risk assessment in the Dongting Lake Region, Hunan, Central China. Water Resour. Manag. 2011, 25, 3465-3484. [CrossRef]

94. Hassan, Z.; Shabbir, R.; Ahmad, S.S.; Malik, A.H.; Aziz, N.; Butt, A.; Erum, S. Dynamics of land use and land cover change (LULCC) using geospatial techniques: A case study of Islamabad Pakistan. SpringerPlus 2016, 5, 1-11. [CrossRef]

95. Mather, P.M.; Koch, M. Computer Processing of Remotely-Sensed Images: An Introduction, 4th ed.; John Wiley \& Sons: Hoboken, NJ, USA, 2011; p. 434.

96. Ha, T.V.; Tuohy, M.; Irwin, M.; Tuan, P.V. Monitoring and mapping rural urbanization and land use changes using Landsat data in the northeast subtropical region of Vietnam. Egypt. J. Remote Sens. Space Sci. 2020, 23, 11-19. [CrossRef]

97. Congalton, R.G.; Green, K. Assessing the Accuracy of Remotely Sensed Data: Principles and Practices; CRC Press: Boca Raton, FL, USA, 2019.

98. Anderson, J.R. A Land Use and Land Cover Classification System for Use with Remote Sensor Data; US Government Printing Office: Washington, DC, USA, 1976; Volume 964. 
99. Saaty, T.L. Multicriteria Decision Making: The Analytic Hierarchy Process: Planning, Priority Setting Resource Allocation; RWS Pubns: Pittsburgh, PA, USA, 1990.

100. Malmir, M.; Zarkesh, M.M.K.; Monavari, S.M.; Jozi, S.A.; Sharifi, E. Analysis of land suitability for urban development in Ahwaz County in southwestern Iran using fuzzy logic and analytic network process (ANP). Environ. Monit. Assess. 2016, $188,447$. [CrossRef]

101. Saaty, T.L.; Vargas, L.G. Decision Making with the Analytic Network Process; Springer: Berlin/Heidelberg, Germany, 2006; Volume 282.

102. Alaa, M.A.-A.; Shamsuddin, S.; Ali, K.A.-A. A GIS-based integration of catastrophe theory and analytical hierarchy process for mapping flood susceptibility: A case study of Teeb area, Southern Iraq. Environ. Earth Sci. 2016, 75, 1-19. [CrossRef]

103. Kanani-Sadat, Y.; Arabsheibani, R.; Karimipour, F.; Nasseri, M. A new approach to flood susceptibility assessment in data-scarce and ungauged regions based on GIS-based hybrid multi criteria decision-making method. J. Hydrol. 2019, 572, 17-31. [CrossRef]

104. Chakraborty, S.; Mukhopadhyay, S. Assessing flood risk using analytical hierarchy process (AHP) and geographical information system (GIS): Application in Coochbehar district of West Bengal, India. Nat. Hazards 2019, 99, 247-274. [CrossRef]

105. Wu, Y.; Zhong, P.-A.; Zhang, Y.; Xu, B.; Ma, B.; Yan, K. Integrated flood risk assessment and zonation method: A case study in Huaihe River basin, China. Nat. Hazards 2015, 78, 635-651. [CrossRef]

106. Shen, Y.-C.; Chang, S.-H.; Lin, G.T.; Yu, H.-C. A hybrid selection model for emerging technology. Technol. Forecast. Soc. Chang. 2010, 77, 151-166. [CrossRef]

107. Zhang, J. Evaluating regional low-carbon tourism strategies using the fuzzy Delphi-analytic network process approach. J. Clean. Prod. 2017, 141, 409-419. [CrossRef]

108. Zou, Q.; Zhou, J.; Zhou, C.; Song, L.; Guo, J. Comprehensive flood risk assessment based on set pair analysis-variable fuzzy sets model and fuzzy AHP. Stoch. Environ. Res. Risk Assess. 2013, 27, 525-546. [CrossRef]

109. Afzali, A.; Sabri, S.; Rashid, M.; Mohammad Vali Samani, J.; Ludin, A.N.M. Inter-Municipal Landfill Site Selection Using Analytic Network Process. Water Resour. Manag. 2014, 28, 2179-2194. [CrossRef]

110. Zhong, M.; Lin, K.; Tang, G.; Zhang, Q.; Hong, Y.; Chen, X. A Framework to Evaluate Community Resilience to Urban Floods: A Case Study in Three Communities. Sustainability 2020, 12, 1521. [CrossRef]

111. Brooks, N. Vulnerability, risk and adaptation: A conceptual framework. Tyndall Cent. Clim. Chang. Res. Work. Pap. 2003, 38, 1-16.

112. Chang, H.; Pallathadka, A.; Sauer, J.; Grimm, N.B.; Zimmerman, R.; Cheng, C.; Iwaniec, D.M.; Kim, Y.; Lloyd, R.; McPhearson, T.; et al. Assessment of urban flood vulnerability using the social-ecological-technological systems framework in six US cities. Sustain. Cities Soc. 2021, 68, 102786. [CrossRef]

113. Schober, P.; Boer, C.; Schwarte, L.A. Correlation coefficients: Appropriate use and interpretation. Anesth. Analg. 2018, 126, 1763-1768. [CrossRef]

114. Pandey, A.; Singh, S.K.; Nathawat, M. Waterlogging and flood hazards vulnerability and risk assessment in Indo Gangetic plain. Nat. Hazards 2010, 55, 273-289. [CrossRef]

115. Sar, N.; Chatterjee, S.; Adhikari, M.D. Integrated remote sensing and GIS based spatial modelling through analytical hierarchy process (AHP) for water logging hazard, vulnerability and risk assessment in Keleghai river basin, India. Modeling Earth Syst. Environ. 2015, 1, 1-21. [CrossRef]

116. Ho Chi Minh City Statistical Office. Available online: http:/ /www.pso.hochiminhcity.gov.vn/web/guest/niengiamthongke2019 (accessed on 6 February 2020).

117. Fleischhauer, M. The Role of Spatial Planning in Strengthening Urban Resilience; Springer: Dordrecht, The Netherlands, 2008; pp. 273-298.

118. Liu, J.; Shi, Z.-W. Quantifying land-use change impacts on the dynamic evolution of flood vulnerability. Land Use Policy 2017, 65, 198-210. [CrossRef]

119. Vermuyten, E.; Meert, P.; Wolfs, V.; Willems, P. Impact of seasonal changes in vegetation on the river model prediction accuracy and real-time flood control performance. J. Flood Risk Manag. 2020, 13, e12651. [CrossRef]

120. Chang, H.-K.; Tan, Y.-C.; Lai, J.-S.; Pan, T.-Y.; Liu, T.-M.; Tung, C.-P. Improvement of a drainage system for flood management with assessment of the potential effects of climate change. Hydrol. Sci. J. 2013, 58, 1581-1597. [CrossRef]

121. Hartmann, T. Clumsy floodplains and the law: Towards a responsive land policy for extreme floods. Built Environ. 2009, 35, 531-544. [CrossRef]

122. Schanze, J. Flood risk management-a basic framework. In Flood Risk Management: Hazards, Vulnerability and Mitigation Measures; Springer: Berlin/Heidelberg, Germany, 2006; pp. 1-20. [CrossRef]

123. Cui, P.; Li, D. Measuring the Disaster Resilience of an Urban Community Using ANP-FCE Method from the Perspective of Capitals. Soc. Sci. Q. 2019, 100, 2059-2077. [CrossRef]

124. Xu, W.; Zhong, M.; Hong, Y.; Lin, K. Enhancing community resilience to urban floods with a network structuring model. Saf. Sci. 2020, 127, 104699. [CrossRef]

125. Lai, C.-H.; Liao, P.-C.; Chen, S.-H.; Wang, Y.-C.; Cheng, C.; Wu, C.-F. Risk Perception and Adaptation of Climate Change: An Assessment of Community Resilience in Rural Taiwan. Sustainability 2021, 13, 3651. [CrossRef]

126. Alves, A.; Gersonius, B.; Kapelan, Z.; Vojinovic, Z.; Sanchez, A. Assessing the Co-Benefits of green-blue-grey infrastructure for sustainable urban flood risk management. J. Environ. Manag. 2019, 239, 244-254. [CrossRef] 
127. Chan, F.K.S.; Griffiths, J.A.; Higgitt, D.; Xu, S.; Zhu, F.; Tang, Y.-T.; Xu, Y.; Thorne, C.R. "Sponge City" in China-A breakthrough of planning and flood risk management in the urban context. Land Use Policy 2018, 76, 772-778. [CrossRef]

128. Jha, A.K.; Bloch, R.; Lamond, J. Cities and Flooding: A Guide to Integrated Urban Flood Risk Management for the 21st Century; The World Bank: Washington, DC, USA, 2012. [CrossRef] 